Journal of Environmental Science and Sustainable Development

Volume 4

Issue 1 July

Article 2

7-30-2021

\title{
THE INFLUENCES OF PERCEIVED USEFULNESS AND ONLINE SOCIAL NETWORK ATTRIBUTE ON THE INTENTIONS TO SEEK AND SHARE INFORMATION ON INDONESIA'S SMART CITY DIGITAL PLATFORM
}

Juliana Rouli

Department of Management, Faculty of Economic and Business, Universitas Indonesia, Depok, 16424, Indonesia, juliana.r@ui.ac.id

Follow this and additional works at: https://scholarhub.ui.ac.id/jessd

Part of the Life Sciences Commons, and the Social and Behavioral Sciences Commons

\section{Recommended Citation}

Rouli, Juliana (2021). THE INFLUENCES OF PERCEIVED USEFULNESS AND ONLINE SOCIAL NETWORK ATTRIBUTE ON THE INTENTIONS TO SEEK AND SHARE INFORMATION ON INDONESIA'S SMART CITY DIGITAL PLATFORM. Journal of Environmental Science and Sustainable Development, 4(1), 1-30. Available at: https://doi.org/10.7454/jessd.v4i1.1109

This Original Research Article is brought to you for free and open access by the School of Environmental Science at UI Scholars Hub. It has been accepted for inclusion in Journal of Environmental Science and Sustainable Development by an authorized editor of UI Scholars Hub. 


\title{
THE INFLUENCES OF PERCEIVED USEFULNESS AND ONLINE SOCIAL NETWORK ATTRIBUTE ON THE INTENTIONS TO SEEK AND SHARE INFORMATION ON INDONESIA'S SMART CITY DIGITAL PLATFORM
}

\author{
Juliana Rouli $^{1 *}$, Ratih Dyah Kusumastuti ${ }^{1}$, Salsabila Izzati Syalianda ${ }^{1}$, Rahayu Safitri ${ }^{1}$ \\ ${ }^{1}$ Department of Management, Faculty of Economic and Business, Universitas Indonesia, \\ Depok, 16424, Indonesia
}

*Corresponding author: juliana.r@ui.ac.id

(Received: 10 May 2021; Accepted: 14 July 2021; Published: 30 July 2021)

\begin{abstract}
The high population and density of cities in Indonesia raise a number of urban problems that require creative and innovative solutions. One of the steps taken by the municipal government is to implement the concept of smart city, one of which is by utilizing information and communication technology (ICT). The municipal government applies ICT by creating websites and applications to provide a variety of city information and municipal government services to all residents that can also be shared on their online social network. However, it is not clear whether the residents perceive that the provided information is useful and whether the intentions to seek and share information from smart city platform are influenced by the perceived usefulness of the information and the citizen' online social network attributes. Hence, this study was conducted with the aim to analyze the effect of the perceived usefulness of smart city information and social network attributes (number of ties and diversity of ties) on intention to seek and share information on smart city websites and applications in cities in Indonesia. The data were collected using a survey method, involving 1,161 respondents in 8 major cities in Indonesia, namely Jakarta, Bandung, Surabaya, Semarang, Medan, Makassar, Denpasar, and Banjarmasin. The survey results were analyzed using partial least square structural equation modeling (PLS-SEM), and it is concluded that the perceived usefulness of smart city information and the residents' online social network attributes have positive and significant effects on the intention to seek information and intention to share information on smart city websites and apps.
\end{abstract}

Keywords: Indonesia; Intention to seek and share information; Online social network; Perceived usefulness; Smart city.

\section{Introduction}

The population living in cities in various parts of the world continues to increase. In 2018, about 55 percent of global population lived in urban areas and it was estimated that it might continue to grow until reaching 60 percent in 2030 (Aljowder et al., 2019). This increase was also experienced by Indonesia. In 2015, more than half of Indonesia's population lived in urban areas and it is projected to increase to 67 percent in 2035 (BPS, 2020). 
The rapid development of urban areas in Indonesia has spurred increased economic growth and attracted villagers to come looking for work and live permanently in the cities. Population movement or urbanization which continues to increase from year to year has caused various urban problems in various dimensions of life (Harahap, 2013). The high rate of poverty creates social problems such as an increase in slum settlements and crime. Traffic congestion is getting worse which also has an impact on decreasing air quality in cities. Many studies have shown that the level of population concentration in a number of big cities in Indonesia is growing very fast (Harahap, 2013). For instance, in the City of Jakarta, the increasing traffic congestion and travel time have caused high air pollution (Sukarto, 2006). Furthermore, with a high population density, Jakarta also experiences environmental problems such as low water quality, waste that is not handled properly, and frequent flooding (Abraham et al., 2013; Chalik et al., 2011; Yudo \& Said, 2001).

To overcome urban problems, a number of cities have started to implement the concept of smart city. The smart city concept takes advantage of the development of information and communication technology (ICT) to help solving urban problems (Chong et al., 2018). ICT acts as a means as well as resource to improve the quality of life, creating an open and innovative urban context through participatory governance while preserving the survival of future generations (L. G. Anthopoulos \& Tougountzoglou, 2012). One form of ICT use in implementing smart city concept is the creation of internet-based websites and applications that contain a number of city information and services provided by the municipal government to its citizen (Angelidou et al., 2018; Anthopoulos, 2017).

Government information and services displayed on websites and mobile applications can vary widely. For example, the City of Jakarta has Jakarta Smart City (JSC) website and JAKI application. The JSC website displays information related to closed-circuit television (CCTV) locations, schools, health units, locations affected by disasters, and locations of brawls (JSC LAB, 2020), while JAKI is an application that consists of various features to search for a number of information such as Air Quality Index (AQI), information on water levels, and flood-affected areas in Jakarta, information on food commodity prices in Jakarta, and the latest information on developments in COVID-19 number of cases in Jakarta (JSC LAB, 2020).

The municipal government strives to provide useful information through all smart city websites and applications that can be used by the residents to make decisions in their daily life. They spent a significant amount of funds for the development of smart city platforms. 
However, it is not clear if the city residents perceive that the information on websites and smart city applications is useful, and if the perceive usefulness of information has an influence on the intention of city residents to seek and share information on these digital platforms.

Meanwhile, internet use in Indonesia has increased during the period of 2017-2019, and the percentage of population accessing the internet in 2017 was around 32.34 percent, increased up to 47.69 percent in 2019 (BPS, 2020). According to Central Bureau of Statistics (BPS) Indonesia, there are three main objectives of the community in accessing the internet such as to use online social media, searching for news/information, and getting entertainment. Some of online social media that are frequently used by public are Facebook (FB), Twitter, Instagram, and WhatsApp (WA) (Nuseir, 2020). An individual can have more than several accounts on online social media and join several groups or online communities with members from different backgrounds. Online social media users can share the information they have and find the information they need on online communities that they follow. They form a virtual/online social network, in which information is exchanged, similar to a physical social network (Anthopoulos \& Fitsili, 2015). In the context of smart city, it is interesting to investigate whether online social network attributes, namely the number of online social media communities that they follow and the level of diversity of members in each community have influences on the intentions of city residents to look for and share information in smart city websites and applications.

Park et al. (2014) indicated that only a few studies that investigated the antecedents of the intentions to seek and share information simultaneously. Furthermore, Pinochet et al. (2019) also stated that not many studies have discussed the perceived usefulness of information and the intention to seek and share information in the context of smart city. Wang and Zhao (2017), on the other hand, mentioned that only few studies that focus on weak ties on online social network. Hence, this study aims to fill these gaps by analyzing the influence of the perceptions of city residents on the usefulness of information displayed on smart city websites and applications and online social network attributes on the intentions to seek and share information on the website and applications of a smart city. The results of this study are expected to provide input for municipal government in developing smart city digital platforms that can be maximally utilized by city residents. 


\subsection{The Smart City concept}

The concept of smart city emerges along with the growth of urbanization in cities, as well as technological developments and their implementations. Smart city is defined differently, and various terms are used to represent the concept (Hollands, 2008; Nam \& Pardo, 2011). A smart city is often defined as the integration existing in urban areas to help the lives of their residents (Giffinger et al., 2007; Pinochet et al., 2019; Van Soom, 2009). A smart city can be built with a "smart" implementation in the following dimensions: smart economy, smart people, smart governance, smart mobility, smart environment, and smart living (Giffinger et al., 2007; Shapiro, 2006; Van Soom, 2009). "Smart" in this term is often associated with the use of technology in optimizing the application of aspects related to urban development, in order to increase urban growth and life quality of its residents (Anthopoulos et al., 2016; Lombardi et al., 2012).

The efficient use of technology in realizing smart cities can be made possible by the support of adequate infrastructure. The infrastructure itself is not limited on physical infrastructure only, but also including information technology (IT) and social infrastructure (Harrison et al., 2010). Van Soom (2009) states that investment in infrastructure will support economic growth which will also improve life quality of urban residents. The investment required in technology was mentioned by Washburn et al. (2009), especially in the development of service infrastructure for the community, such as city administration, education, health, security, transportation, housing, and other important infrastructures. Therefore, cities can utilize their resources, and carry out maintenance and supervision of existing infrastructure. The integration among aspects can be realized through the use of technology, with physical infrastructure as the foundation, IT infrastructure as the factor that creates interconnection among aspects in the city, and social infrastructure in the form of social networks (Washburn et al., 2009).

As previously mentioned, social infrastructure plays an important role in building a smart city, and the term "human capital" is mentioned in various interpretations of smart cities. Lombardi et al., (2012) state that smart cities are not limited to the use of infrastructure and information technology, but also focusing on human, social, and environmental resources. Technology combined with decision making a conscious and independent society will support urban growth (Giffinger et al., 2007). Chourabi et al. (2012) divide eight critical factors in cities, namely: (1) management and organization, (2) technology, (3) governance, (4) policy, (5) society and community, (6) economy, (7) built infrastructure, and (8) natural 
resources. Four of the eight critical factors relate to the quality of human resources and show their important contribution to the success of a smart city.

Several definitions of smart city are also related to improving life quality, and also mention the existence of sustainability as the goal of a smart city (Caragliu et al., 2011; Toppeta, 2010; Van Soom, 2009). Toppeta (2010) defines a smart city as a city that allows a combination of technology with organizational planning and design to accelerate processes, to enable innovation and solutions to urban complexity, and to increase sustainability and viability.

Various frameworks for measuring smart city performance have been developed with various approaches, such as European Smart Cities Ranking (Giffinger et al., 2007)) and Integrative Framework (Chourabi et al., 2012) to measure the level of intelligence or "smartness" of a city, where society or "human capital" is an important determining factor. Giffinger et al. (2007) mentioned the existence of "awareness" of urban awareness of a smart city as an important aspect. The awareness of the city community can occur because of simultaneous integration with technology, where the city community is the party receiving city information, and at the same time becomes the party that also encourages the emergence of information (Pinochet et al., 2019).

\subsection{Smart City information}

City information refers to the use of technology to digitally collect information from a community or society and convey it to public through a website portal (Sairamesh et al., 2004; Sproull \& Patterson, 2004; Widmayer, 1999). Moss Kanter \& Litow (2009) revealed that various technology applications in every aspect of a smart city are not sufficient to create smartness in the city and realize the goals of a smart city if there is nothing to encourage interconnection among aspects. For example, a smart and connected city has people who can obtain "common goods" such as education, employment information, access to health facilities, and access to water and other resources more easily and efficiently. To make it happen, cities need to strike a balance in integrating information related to these "common goods" (Kanter \& Litow, 2009). For example, the implementation of a digital city in South Korea has gone through urban infrastructure planning stage to its implementation. South Korea is building a smart city by digitizing aspects of the city known as a "digital city" (Anthopoulos, 2017). Urban communities in South Korea can obtain and access information and public services. Thus, they succeed in gaining the trust of their people to share the same 
digital knowledge (L. Anthopoulos \& Fitsilis, 2010). South Korea applies the use of "computing" in an urban environment with e-Government. The South Korean government in collaboration with the private sector has developed up to 70 applications for public services in 2013. Apart from South Korea, Singapore as one of the countries implementing smart cities has also invested in an integrated transportation system to provide traffic information to public (GSMA, 2013).

Information makes cities habitable for their people (Sproull \& Patterson, 2004). In an era that uses internet and websites to access information, information exchange is carried out via internet and social media, including city information. Sproull et al. (2004) mentioned the importance of voluntary community participation in city information sharing. Meanwhile, organizations in society, in this case the city government, have a role in integrating public information that is shared digitally and directly or known as real-time.

\subsection{Intentions to seek and share information}

The activities of seeking and sharing information are two main activities in online community. The intention to seek information is one of activities in human information behavior (HIB), including information use and information sharing (Wilson, 2000). Information-seeking intention itself has been discussed in various models, especially in the fields of learning or education, health, and leisure (Savolainen, 2019). Information-seeking intention or seeking information behavior is defined as seeking information in various ways to find and access information in response to goals (Savolainen, 2019). This information search includes human sources or systems, such as World Wide Web (WWW).

Information sharing is defined as the act of providing information to other community members who need the information (Gardoni et al., 2002). Information sharing commonly occurs both ways and is entirely voluntary in online communities. The theory of organizational motivation states that the benefits to the organization are perceived as more important than the benefits felt by each individual, and this understanding motivates individuals to help other individuals that they do not know in the same organization (Constant et al., 1994). A weak tie community has similarities to an organization. If an individual gets benefits from his community, then he/she will be willing to help other members of the community because this is a reciprocity norm (Berkowitz \& Daniels, 1964; Titmuss, 2018). 


\subsection{Perceived usefulness of the information}

Davis (1989) introduced technology acceptance model (TAM) based on the theory of reasoned action (TRA) by Fishbein and Ajzen (1975). TAM explained factors that determine computer acceptance and general user behavior across different end-user computing technologies and user populations, whereas TRA addressed general human behaviour (Davis et al., 1989). According to TAM, the desire to adopt a technology or behavior depends on the belief in the usefulness of technology or behavior. TAM used two constructs, perceived usefulness (PU) and perceived ease of use (EU), to explain computer usage behavior. The degree to which a person believes that employing a given system would improve his or her job performance is described as PU, while the degree to which a person believes that using a specific system would be free of effort has been termed as EU (Venkatesh \& Davis, 2000).

A study conducted by Sussman \& Siegal (2003) which integrates TAM theory and informational influence to measure the information adoption process indicates that perceived usefulness is an antecedent of information adoption by users.

Perceived usefulness is also related to an increase in productivity (Sussman \& Siegal, 2003; Chau, 1996). Sussman \& Siegal (2003) measure perceived usefulness based on how the information obtained is valuable, informative, and helpful. In a study conducted by Park et al. (2014) which examined the online investor community, investors used stock message boards to find information about investment because they believed that the information they got could be very helpful in making investment decisions.

Pinochet et al. (2019) model perceived usefulness and its relationship to the intention to live in a smart city, and define perceived usefulness of city information as the level at which individuals perceive city information as useful and contribute to carrying out activities more quickly and with higher quality. The correlation between perceived usefulness and information-seeking intention can be explained by the theory of weak ties. This theory states that more new information is obtained by an individual from weak ties than through strong connections (Granovetter, 1973;1983). The main reason is that members of the network with strong attachments (such as friends, colleagues, and family members) often have the same background, and hence, have the same information sources. Therefore, they participate in an online community to find certain information that is not found in networks with strong attachments (Ellison et al., 2007).

The social capital theory also indicates that individuals will engage in social relationships if they expect to benefit from the contributions they make (Anthopoulos, 2017). The 
reciprocity characteristic of relational social capital also explains the relationship between perceived usefulness and participation. Reciprocity means indebted to each other, and individuals will adjust their contributions according to the benefits that they receive (Wasko \& Faraj, 2005).

Park et al. (2014) examine the intention to seek and share information on online community website, and of the various factors that cause this behavior; perceived usefulness is one of them that has a positive effect. Perceived benefits can encourage online social network users to participate more actively through searching and sharing information on these networks. Based on these explanations, we conclude the following hypotheses.

H1a: Perceived usefulness of smart city information has positive effect on the intention to seek information on smart city websites/applications.

H1b: Perceived usefulness of smart city information has positive effect on the intention to share information on smart city websites/applications and online social network.

\subsection{Online social network attributes (Number of ties and diversity of ties)}

Social networks can be defined as a structure of relationships that connect individuals or groups of individuals (Hampton, 2011). Previous studies have shown that the number of ties and diversity of ties affect the quality of interactions among members of social networks (Hampton, 2011; Sanz-Cruzado \& Castells, 2018; Skvoretz, 2013). The number of ties increases the possibility of obtaining information, as well as sharing information and maintaining relationships on social networks (Sanz-Cruzado \& Castells, 2018). Meanwhile, the diversity of ties on social networks adds an option to collect information (Isaac \& Matous, 2017; Sanz-Cruzado \& Castells, 2018). These explanations indicate that online social network attributes are related to searches and various information on social networks. Thus, the following hypotheses can be made.

H2a: Number of ties has positive effect on the intention to seek information on smart city website/applications.

$\mathrm{H} 2 \mathrm{~b}$ : Number of ties has positive effect on the intention to share information on smart city websites/applications and online social network.

H3a: Diversity of ties has positive effect on the intention to seek information on smart city websites/applications.

$\mathrm{H} 3 \mathrm{~b}$ : Diversity of ties has positive effect on the intention to share information on smart city websites/applications and online social network. 


\section{Methods}

\subsection{Research model}

This research used quantitative method. The study had 3 (three) independent variables and 2 (two) dependent variables. The independent variables included perceived usefulness of smart city information, number of ties, and diversity of ties. Meanwhile, the dependent variables consisted of intention to seek information on smart city websites/applications., and intention to share information on smart city websites/applications and online social network. The research model is presented in Figure 1.

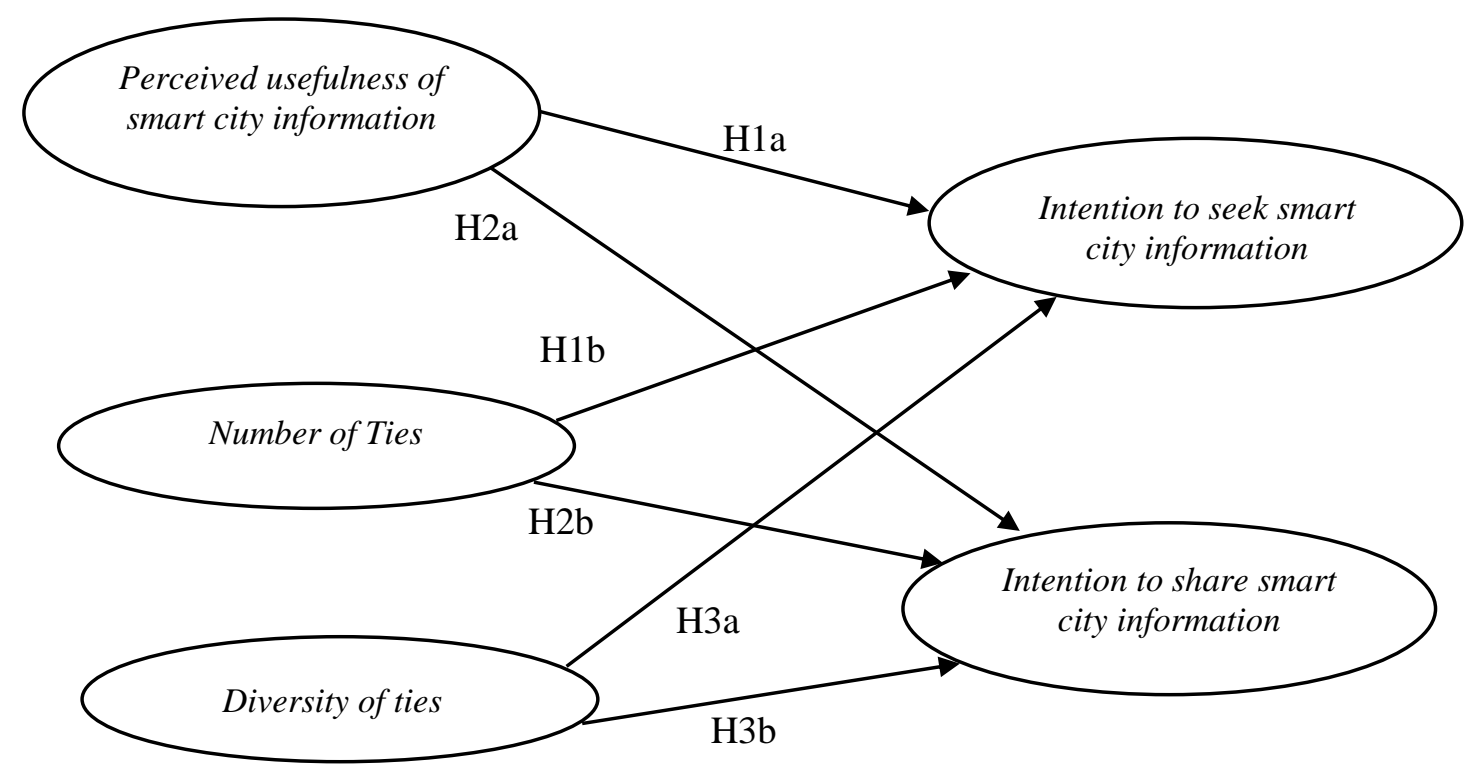

Figure 1. Research Model

\subsection{Research variables and data collections}

The data used in this study were primary data obtained through online survey. The survey was conducted in November and December 2020 in 8 major cities in Indonesia that have implemented the smart city concept, namely Jakarta, Bandung, Surabaya, Semarang, Medan, Makassar, Denpasar and Banjarmasin. The sampling method used was purposive sampling method since the respondents were residents who lived in these big cities and had accessed the web and/or smart city application belonging to the respective city government. The respondents were the residents that had opened/used smart city website and/or application in the respective city in the last 3 months.

The questionnaires were distributed to 1200 respondents, however only 1,161 questionnaires were completed. Respondents were asked to fill out a questionnaire consisting 
of screening questions, respondent profile questions, and question items for each variable as shown in Table 1. Each question for the variables of perceived usefulness of information, intention to seek information, and intention to share information is measured using a Likert scale of 1-6 (strongly disagree - strongly agree). Question items for the variables of number of ties and diversity of ties are measured by referring to a scale of 1-6 based on the number of accounts/friends/followers/contacts/groups as well as the diversity of friends that they have on online social network. For variable of number of ties, the scale for question item NOT1 is $1=1$ account, $2=2$ accounts, $3=3$ accounts, $4=4$ accounts, $5=5$ accounts, and $6=\geq 6$ accounts. However, for question items NOT2 to NOT7, the scale is $1=0-100,2=101-200,3=201-300$, $4=301-400,5=401-500$, and $6=\geq 501$ friends/followers/contacts, while the scale for question item NOT8 is $1=0-5,2=6-10,3=11-15,4=16-20,5=21-25$, and $6=\geq 6$ WA Groups. Regarding the variable of diversity of ties (DOT), scale 1 shows the lowest level of diversity and scale 6 shows the highest level of diversity of friends on online social network.

Before the questionnaire was distributed, a wording test was conducted with six individuals to ensure that the questions posed could be understood by prospective respondents. Based on the results of the wording test, the questionnaire was revised according to the input from respondents. The operationalization of the variables is presented in Table 1 .

Table 1. Operationalization of variables

\begin{tabular}{|c|c|c|c|}
\hline Variable and Its Definition & Indicators & Scale & Reference \\
\hline $\begin{array}{l}\text { Perceived Usefulness of Smart City } \\
\text { Information (PCU) } \\
\text { Definition: The trust level of an } \\
\text { individual that information } \\
\text { displayed on smart city website/ } \\
\text { application in their city is beneficial } \\
\text { (Saadé \& Bahli, 2005) }\end{array}$ & $\begin{array}{l}\text { 1. Information displayed on } \\
\text { smart city website/ } \\
\text { application of my city is } \\
\text { complete. (PCU1) } \\
\text { 2. Information displayed on } \\
\text { smart city website/ } \\
\text { application of my city is in } \\
\text { accordance with what } \\
\text { residents need. (PCU2) } \\
\text { 3. Information displayed by } \\
\text { smart city website/ } \\
\text { application in my city is up } \\
\text { to date. (PCU3) }\end{array}$ & Likert $1-6$ & $\begin{array}{l}\text { Adapted from } \\
\text { (Sussman \& Siegal, } \\
\text { 2003) for smart city } \\
\text { problem }\end{array}$ \\
\hline Number of Ties (NOT) & $\begin{array}{l}\text { 1. Number of online social } \\
\text { media accounts (NOT1) }\end{array}$ & Likert $1-6$ & Park et al. (2010) \\
\hline
\end{tabular}




\begin{tabular}{|c|c|c|c|}
\hline Variable and Its Definition & Indicators & Scale & Reference \\
\hline $\begin{array}{l}\text { Definition: Number of friends, } \\
\text { acquaintance or collegue on online } \\
\text { social network (Granovetter, 1973; } \\
\text { 1983; Constant et al., 1996) }\end{array}$ & $\begin{array}{ll}\text { 2. } & \text { Number of friends on } \\
\text { Facebook (NOT2) } \\
\text { 3. Number of followers on } \\
\text { Instagram (NOT3) } \\
\text { 4. Number of accounts } \\
\text { followed on Instagram } \\
\text { (NOT4) } \\
\text { 5. Number of followers on } \\
\text { Twitter (NOT5) } \\
\text { 6. Number of accounts } \\
\text { followed on Twitter (NOT6) } \\
\text { 7. Number of contacts on WA } \\
\text { (NOT7) } \\
\text { 8. Number of WA groups } \\
\text { joined (NOT8) }\end{array}$ & & \\
\hline $\begin{array}{l}\text { Diversity of Ties (DOT) } \\
\text { Definition: Diversity of friends' } \\
\text { background on online social } \\
\text { network (Constant et al., 1996; } \\
\text { Granovetter, 1973; Zorzi, 2019) }\end{array}$ & $\begin{array}{l}\text { 1. Diversity of friends in social } \\
\text { media account such as } \\
\text { FB/Instagram/Twitter. } \\
\text { (DOT1) } \\
\text { 2. Diversity of friends in Group } \\
\text { of WA Account. (DOT2) }\end{array}$ & Likert 1 - 6 & Park et al. (2010) \\
\hline $\begin{array}{l}\text { Intention to Seek Smart City } \\
\text { Information (ISK) } \\
\text { Definition: The intention to search } \\
\text { for data and information from smart } \\
\text { city website/application } \\
\text { (Wilson, 2000). }\end{array}$ & $\begin{array}{l}\text { 1. I intend to access Smart City } \\
\text { Website/ application of my } \\
\text { city to seek city information. } \\
\text { (ISK1) } \\
\text { 2. I intend to access Smart City } \\
\text { Website/ application of my } \\
\text { city to seek latest city } \\
\text { information. (ISK2) } \\
\text { 3. I intend to access Smart City } \\
\text { Website/ application of my } \\
\text { city to know about the latest } \\
\text { situation/ regulation in my } \\
\text { city. (ISK3) }\end{array}$ & Likert 1 - 6 & $\begin{array}{l}\text { Bock et al. (2005) } \\
\text { Park et al. (2014) }\end{array}$ \\
\hline $\begin{array}{l}\text { Intention to Share Smart City } \\
\text { Information (ISR) } \\
\text { Definition: The intention to share }\end{array}$ & $\begin{array}{l}\text { 1. I intend to post the city } \\
\text { information on smart city } \\
\text { website/application of my } \\
\text { city. (ISR1) }\end{array}$ & Likert 1 - 6 & Bock et al. (2005) \\
\hline
\end{tabular}




\begin{tabular}{lll}
\hline Variable and Its Definition & Indicators & Reference \\
\hline information about the city on smart & 2. I intend to post city \\
city website/application and on & information more frequently \\
online social network (Gardoni et & on Smart City \\
al., 2002). & Website/application of my \\
& city. (ISR2) \\
3. & If asked, I will post the city \\
& information on smart city \\
& website/application of my \\
& city. (ISR3) \\
4. I intend to forward/retweet & information that I obtain \\
from Smart City Website/ & application of my social \\
media accounts. (ISR4) & 5. I will forward/retweet the \\
information that I obtain & from smart city \\
website/application to my & WhatsApp Groups. (ISR5) \\
&
\end{tabular}

\subsection{Data analysis method}

Data analysis in this study was carried out using partial least square structural equation modeling (PLS-SEM). PLS-SEM has the advantage as it works efficiently on small sample and complex models, where almost no assumptions are underlying the data. The strength of PLS-SEM lies in its large statistical power so that PLS is more likely to show certain significant association as is true of its population than other methods (Hair et al., 2017). There are three stages of analysis in PLS-SEM which consists of outer model analysis, inner model analysis, and hypothesis testing (Hair et al., 2017).

The outer model analysis explains the association between each latent variable and its indicators. Validity and reliability were tested at this stage. There are two types of validity in PLS-SEM (Hair et al., 2017), namely convergent validity and discriminant validity. Convergent validity measures the strength of indicators that reflect latent variables; an indicator is categorized as having convergent validity if it has an outer loading factor $\geq$ of 0.5 (Hair, 2010). Discriminant validity is used to ensure and determine that every concept that exists in each latent variable is different from other latent variables. It is measured through 
the value of cross-loading factor where the loading factors of the latent variable's indicators must be greater than the loading factors of other latent variables' indicators. Furthermore, the reliability and validity tests of latent variables are carried out by referring to Cronbach's Alpha value and composite reliability (for reliability tests), and Average Variance Extracted (AVE) (for validity tests). A latent variable is said to have good reliability if the value of Cronbach's Alpha and composite reliability is $\geq 0.7$ and is said to be valid if the AVE value is $\geq 0.5$ (Hair et al., 2017).

The purpose of inner model analysis in this study was to see the association between latent variables, namely by using R-square of the research model. The higher the value obtained in R-square analysis, the better the prediction model from proposed research model (Hair et al., 2017).

Hypothesis testing, on the other hand, was determined based on testing through the bootstrapping method. This method is used to measure t-statistic and p-value with t-statistic of more than 1.96 and a p-value of $\leq 0.05$ (Hair et al., 2017).

\section{Results and Discussions}

\subsection{Descriptive statistics}

Table 2 shows the profiles of survey respondents that were classified based on gender, age, highest education level, occupation, and the sources of information regarding smart city website and application. As can be seen, in terms of gender, there were relatively similar proportions of male and female respondents. Furthermore, almost 54\% of respondents were in the range of 20-29 years old, which was the age range whereby the most internet and social media user in Indonesia (KOMINFO, 2017). Based on the highest education level, 93\% of the respondents graduated from senior high school and above, and $81 \%$ of the respondents' occupations were employee, student/college student and housewife. Furthermore, $81 \%$ of respondents know about smart city website/application from local government's social media account and from their friends/family/siblings. This shows that social media and relatives are more effective in conveying information about smart city websites and applications. 
Table 2. Descriptive Statistics of Respondents' Profile

\begin{tabular}{|c|c|c|}
\hline Characteristics & Category & Percentage \\
\hline \multirow[t]{2}{*}{ Gender } & Male & $52 \%$ \\
\hline & Female & $48 \%$ \\
\hline \multirow[t]{9}{*}{ Age (years old) } & $15-19$ & $9 \%$ \\
\hline & $20-24$ & $33 \%$ \\
\hline & $25-29$ & $21 \%$ \\
\hline & $30-34$ & $15 \%$ \\
\hline & $35-39$ & $11 \%$ \\
\hline & $40-44$ & $5 \%$ \\
\hline & $45-49$ & $4 \%$ \\
\hline & $50-54$ & $2 \%$ \\
\hline & 55 or more & $1 \%$ \\
\hline \multirow[t]{6}{*}{ Highest Education } & Elementary School (SD) & $2 \%$ \\
\hline & Junior High School (SLTP) & $5 \%$ \\
\hline & Senior High School (SLTA) & $51 \%$ \\
\hline & Diploma 1, 2, 3 (D1/D2/D3) & $11 \%$ \\
\hline & Diploma 4/Bachelor Degree (D4/ S1) & $30 \%$ \\
\hline & Master Degree/Doctoral Degree (S2/S3) & $1 \%$ \\
\hline \multirow[t]{6}{*}{ Occupation } & Housewife & $14 \%$ \\
\hline & Employee & $38 \%$ \\
\hline & Student/College Student & $29 \%$ \\
\hline & Civil Servant (PNS) & $5 \%$ \\
\hline & Entrepreneur & $13 \%$ \\
\hline & Others & $2 \%$ \\
\hline \multirow{5}{*}{$\begin{array}{l}\text { Source of Information about smart city } \\
\text { website/application }\end{array}$} & Mass Media (news site/newspapaer/others) & $8 \%$ \\
\hline & Social Media Account of Local Government & $46 \%$ \\
\hline & Government Employee (City, Sub District, Urban & \\
\hline & Village) & $11 \%$ \\
\hline & Friends/Family/Siblings & $35 \%$ \\
\hline
\end{tabular}

In addition to information regarding the respondents' profile, websites and applications that are opened or used most frequently by respondents in each city are presented in Figure 2. 


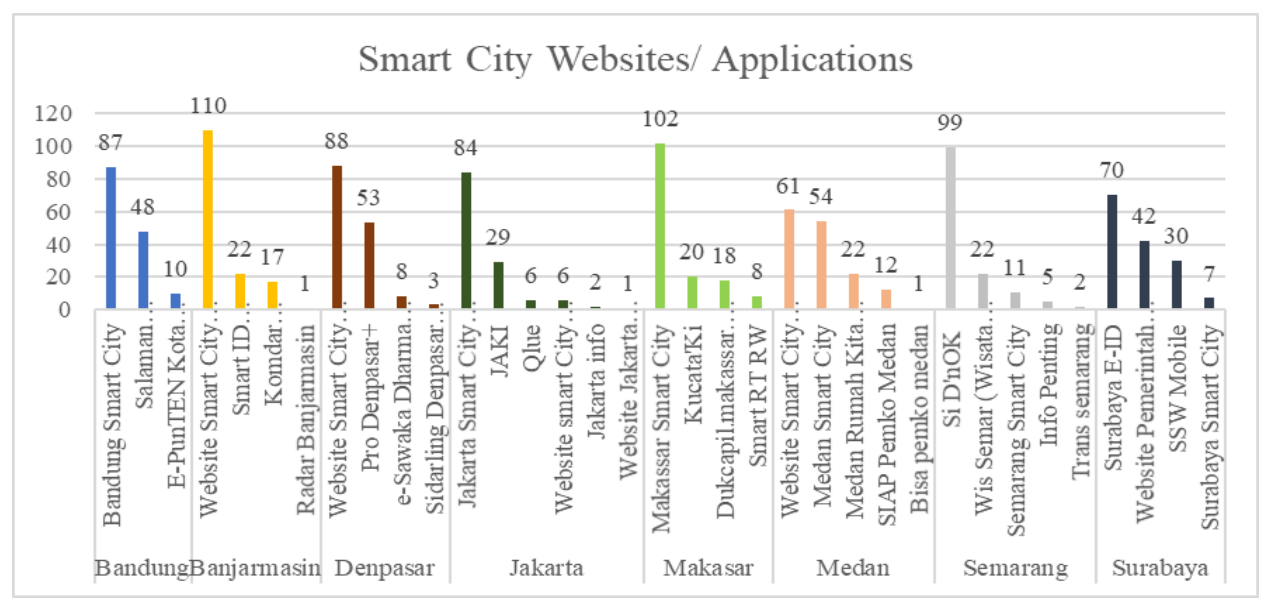

Figure 2. Websites / Applications Frequently Opened / used by Respondents

Figure 2 shows that each city has a number of different websites and applications to provide services to its citizen in order to implement smart city concept. The followings are a number of websites and applications that are frequently used by respondents, namely Jakarta Smart City, Makassar Smart City, Banjarmasin Smart City, Si D’nok and Surabaya E-ID.

Table 3. Descriptive Statistics of Variables

\begin{tabular}{clcc}
\hline No & Variables & Mean & Standard Deviation \\
\hline 1 & PCU & 4.63 & 0.71 \\
2 & NOT & 2.89 & 1.1 \\
3 & DOT & 3.73 & 1.39 \\
4 & ISR & 4.3 & 0.9 \\
5 & ISK & 4.59 & 0.8 \\
\hline
\end{tabular}

Table 3, on the other hand, shows descriptive statistics of the variables, and the mean of PCU is 4.63 , which means that on average, respondents tend to agree that information presented on smart city websites/applications is complete, meet their daily needs and up to date. Furthermore, the average of NOT is 2.89 , showing that respondents have low to moderate number of accounts and friends on social media. Meanwhile, in terms of Diversity of Ties (DOT) the average value is 3.73, indicating that respondents have moderate level of diversity of friends. Last, the average value of ISR (4.3) and ISK (4.59) showing that respondents tend to have the intentions to seek and share information on smart city websites/applications. 


\subsection{Data analysis using PLS-SEM}

All hypotheses mentioned in the previous section were tested using PLS-SEM. The followings are the results of data processing and analysis using SmartPLS program.

\subsubsection{Outer model analysis}

In outer model analysis, the convergent and discriminant validity tests of all indicators were carried out and the validity and reliability tests of all latent variables were carried out. This was conducted by looking at the value of outer loading factor or standardized loading factor (SLF) (see Table 4).

Table 4. Outer Loading Factor Values

\begin{tabular}{|c|c|c|c|c|c|}
\hline & DOT & ISK & ISR & NOT & PCU \\
\hline DOT1 & 0.847 & & & & \\
\hline DOT2 & 0.963 & & & & \\
\hline ISK1 & & 0.918 & & & \\
\hline ISK2 & & 0.924 & & & \\
\hline ISK3 & & 0.929 & & & \\
\hline ISR1 & & & 0.872 & & \\
\hline ISR2 & & & 0.876 & & \\
\hline ISR3 & & & 0.859 & & \\
\hline ISR4 & & & 0.762 & & \\
\hline ISR5 & & & 0.789 & & \\
\hline NOT1 & & & & 0.737 & \\
\hline NOT2 & & & & 0.756 & \\
\hline NOT3 & & & & 0.232 & \\
\hline NOT4 & & & & 0.220 & \\
\hline NOT5 & & & & 0.501 & \\
\hline NOT6 & & & & 0.543 & \\
\hline NOT7 & & & & 0.653 & \\
\hline NOT8 & & & & 0.568 & \\
\hline PCU1 & & & & & 0.871 \\
\hline PCU2 & & & & & 0.897 \\
\hline PCU3 & & & & & 0.897 \\
\hline
\end{tabular}

As can be seen in Table 4, most of indicators have a loading factor value of more than 0.5 . However, some indicators, NOT3 and NOT4, have a loading factor value of less than 0.5 . Indicators with very low Indicator values should be removed from their latent constructs or variables (Hair et al., 2011). Indicators are removed one by one by considering changes in the DOI: https://doi.org/10.7454/jessd.v4i1.1063 
loading factor value of other indicators and also values for other tests. When the indicator with the smallest loading factor is removed, namely NOT4, other loading factor values and also the values for other tests will increase, except for AVE (Average Variance Extracted) value which is still below 0.5 . Therefore, several indicators with the next smallest loading factors value are removed. Overall, the indicators omitted are NOT3, NOT4, NOT5, and NOT6. Table 5 presents the loading factors after four indicators have been removed.

Table 5. Outer Loading Factor (without NOT3, NOT4, NOT5, NOT6)

\begin{tabular}{|c|c|c|c|c|c|}
\hline & DOT & ISK & ISR & NOT & PCU \\
\hline DOT1 & 0.847 & & & & \\
\hline DOT2 & 0.964 & & & & \\
\hline ISK1 & & 0.918 & & & \\
\hline ISK2 & & 0.924 & & & \\
\hline ISK3 & & 0.929 & & & \\
\hline ISR1 & & & 0.870 & & \\
\hline ISR2 & & & 0.875 & & \\
\hline ISR3 & & & 0.859 & & \\
\hline ISR4 & & & 0.765 & & \\
\hline ISR5 & & & 0.788 & & \\
\hline NOT1 & & & & 0.734 & \\
\hline NOT2 & & & & 0.803 & \\
\hline NOT7 & & & & 0.667 & \\
\hline NOT8 & & & & 0.623 & \\
\hline PCU1 & & & & & 0.871 \\
\hline PCU2 & & & & & 0.897 \\
\hline PCU3 & & & & & 0.897 \\
\hline
\end{tabular}

Table 5 shows that all indicators already have a loading factor value of more than 0.5 . This indicates that all of these indicators have good convergent validity. The next step is to test the discriminant validity by looking at the value of cross-loading factor. The results of the data processing are presented in Table 6. The table explains that the loading factor of each indicator aimed at the latent variable is greater than the loading factor of these indicators when aimed at other latent variables. Thus, it can be said that all indicators have good discriminant validity as well. 
Table 6. Value of Cross Loading Factor

\begin{tabular}{llllll}
\hline & DOT & ISK & ISR & NOT & PCU \\
\hline DOT1 & $\mathbf{0 . 8 4 7}$ & 0.082 & 0.095 & 0.213 & 0.079 \\
DOT2 & $\mathbf{0 . 9 6 4}$ & 0.158 & 0.195 & 0.324 & 0.102 \\
ISK1 & 0.151 & $\mathbf{0 . 9 1 8}$ & 0.666 & 0.128 & 0.540 \\
ISK2 & 0.112 & $\mathbf{0 . 9 2 4}$ & 0.647 & 0.105 & 0.562 \\
ISK3 & 0.135 & $\mathbf{0 . 9 2 9}$ & 0.616 & 0.105 & 0.565 \\
ISR1 & 0.097 & 0.626 & $\mathbf{0 . 8 7 0}$ & 0.168 & 0.481 \\
ISR2 & 0.088 & 0.612 & $\mathbf{0 . 8 7 5}$ & 0.133 & 0.474 \\
ISR3 & 0.168 & 0.599 & $\mathbf{0 . 8 5 9}$ & 0.192 & 0.472 \\
ISR4 & 0.182 & 0.488 & $\mathbf{0 . 7 6 5}$ & 0.394 & 0.346 \\
ISR5 & 0.192 & 0.567 & $\mathbf{0 . 7 8 8}$ & 0.284 & 0.407 \\
NOT1 & 0.255 & 0.056 & 0.197 & $\mathbf{0 . 7 3 4}$ & 0.029 \\
NOT2 & 0.171 & 0.120 & 0.265 & $\mathbf{0 . 8 0 3}$ & 0.030 \\
NOT7 & 0.263 & 0.105 & 0.162 & $\mathbf{0 . 6 6 7}$ & 0.059 \\
NOT8 & 0.238 & 0.049 & 0.144 & $\mathbf{0 . 6 2 3}$ & 0.017 \\
PCU1 & 0.099 & 0.494 & 0.453 & 0.066 & $\mathbf{0 . 8 7 1}$ \\
PCU2 & 0.089 & 0.558 & 0.458 & 0.027 & $\mathbf{0 . 8 9 7}$ \\
PCU3 & 0.086 & 0.550 & 0.487 & 0.033 & $\mathbf{0 . 8 9 7}$ \\
\hline
\end{tabular}

The final stage of outer model analysis is to test the validity and reliability of each latent variable. The reliability test is measured by the Composite Reliability (CR) value, while the validity test is measured by the Average Variance Extracted (AVE) value. Table 7 shows the value of these two measures for each latent variable.

Table 7. Results of Variable Validity and Reliability Tests

\begin{tabular}{lcc}
\hline Latent Variable & $\begin{array}{c}\text { Composite Reliability } \\
(\mathrm{CR})\end{array}$ & $\begin{array}{c}\text { Average Variance } \\
\text { Extracted (AVE) }\end{array}$ \\
\hline DOT & 0.902 & 0.823 \\
ISK & 0.946 & 0.853 \\
ISR & 0.919 & 0.694 \\
NOT & 0.801 & 0.504 \\
PCU & 0.918 & 0.789 \\
\hline
\end{tabular}


A latent variable is categorized as having good reliability if the composite reliability value is more than 0.7 and is said to be valid if the AVE value is more than 0.5 (Hair et al., 2017). The values in Table 7 show that all variables have a composite reliability value $\geq 0.7$ therefore it can be concluded that all latent variables in this study are reliable. The AVE values of all variables are also more than 0.5 , indicating that all variables have good validity.

Inner model analysis or structural model is intended to test the association between the dependent variable and the independent variables based on R-square concept and all research hypotheses. The results of data processing for R-square value are shown in Table 8.

Table 8. R Square Value

\begin{tabular}{lcc}
\hline & R Square & R Square Adjusted \\
\hline ISK & 0.374 & 0.373 \\
ISR & 0.343 & 0.342 \\
\hline
\end{tabular}

The R-square value of variable ISK is 0.374 indicating that $37.4 \%$ of the data variation can be explained by ISK model (a model that shows the influences of PCU, NOT, and DOT variables on ISK variable) while the rest is explained by other variables. The same thing also occurs to ISR variable, where the value of 0.343 indicates that $34.3 \%$ of the data variation can be explained by the ISR model (a model that shows the effects of PCU, NOT, and DOT variables on the ISR variable), and the rest is explained by other variables. Generally, the higher the R-square value, the better the model will explain the association between variables. However, Cohen (2013) states that specifically for the field of social and behavioral sciences, R-square $=2 \%$ is classified as having a weak effect, R-square $=13 \%$ is classified as having a moderate effect, and R-square $=26 \%$ is classified as having a strong effect. This research is in the field of social and behavioral sciences, hence the R-square value of $37.4 \%$ in the ISK model and $34.3 \%$ in the ISR model indicate that both are good models to explain the association between variables.

\subsubsection{Hypothesis testing}

The next stage is testing the research hypothesis, and the results are presented in Table 9. 
Table 9. Hypothesis Test

\begin{tabular}{lllll}
\hline Hypotheses & Path Coefficient & P-Values & T - Values & Test Result \\
\hline H1a: PCU $\rightarrow$ ISK & 0.591 & 0.000 & 25.792 & $\begin{array}{l}\text { Hypothesis is } \\
\text { supported }\end{array}$ \\
H1b: PCU $\rightarrow$ ISR & 0.504 & 0.000 & 22.451 & $\begin{array}{l}\text { Hypothesis is } \\
\text { supported }\end{array}$ \\
H2a: NOT $\rightarrow$ ISK & 0.076 & 0.000 & 3.413 & $\begin{array}{l}\text { Hypothesis is } \\
\text { supported }\end{array}$ \\
H2b: NOT $\rightarrow$ ISR & 0.225 & 0.000 & 10.239 & $\begin{array}{l}\text { Hypothesis } \\
\text { supported }\end{array}$ \\
H3a: DOT $\rightarrow$ ISK & & & & Hypothesis \\
supported
\end{tabular}

Table 9 shows that all hypotheses are supported by data. The p-values are $0.000 \leq 0.005$ and the path coefficient is positive in the association between perceived usefulness and intention to seek and intention to share. This indicates that perceived usefulness has a positive and significant effect on the intention to seek and intention to share smart city information. This also means that the better the perception of city residents regarding the benefits of information about smart city, the higher they intend to seek and share information on smart city websites/applications and on their online social network.

The p-value obtained from testing the effect of the number of ties on intention to seek and intention to share smart city information are both 0.000 with positive path coefficients. This shows that perceived usefulness has a positive and significant effect on the intention to seek and intention to share. In other words, the more the number of online social networking accounts and the number of friends on Facebook and WhatsApp and WhatsApp Groups owned by city residents, the higher their intentions to seek for information on smart city websites/applications and share it on the platform and with their friends on social media.

Last are hypotheses testing related to the positive influence of diversity of ties on intention to seek and intention to share smart city information. The test results show p-values of 0.005 for intention to seek and 0.007 for intention to share where the path coefficients are both positive. These two values indicate that the higher the diversity of friends on online social 
networks, the higher urban residents' intention to seek and share information on smart city websites/applications and on their online social network.

\subsection{Discussion}

The results reveal that city residents' perceptions on the usefulness of information on smart city websites and applications developed by the city government greatly influence their desire to seek the smart city information (H1a). This result is in line with results from Park et al. (2014) and Boon-Itt (2019) that investigate the relationships between perceived usefulness of information and information seeking intention on online investment community website and health websites respectively. According to Sussman \& Siegal (2003), the perceived usefulness of information can be measured based on how valuable, informative, and useful/helpful the information is. The results show that the perception of usefulness of information provided on the smart city digital platforms is mainly determined by the suitability of the information to the needs of city residents and whether the information is up to date with the latest situation/condition. These perceptions of suitability and recency of information affect the city residents' intentions to access smart city digital platforms and seek information that they need, especially about the latest situation and regulation in their cities.

The results also show that perception of usefulness of information on smart city digital platforms affects the intention to share the information on the platform and online social network (H1b is supported). The results are in accordance with the conclusions from Park et al.(2014) and Jahmani et al. (2018). The latter indicated that the perceived usefulness of the platform (including the information provided) encouraged the use of the platform for information sharing, which matched with our results, in which, the intention to share smart city information is primarily determined by the residents' intentions to post smart city information on smart city digital platforms and online social network.

The results of the analysis also found that one of the attribute of online social network (number of ties) has positive effects on the intention of city residents to seek and share information on smart city websites/applications ( $\mathrm{H} 2 \mathrm{a}$ and $\mathrm{H} 2 \mathrm{~b}$ are supported). This is in accordance with Weng et al. (2018) and the same as the results by Sanz-Cruzado \& Castells (2018), which states that the number of ties or the number of friends/followers/contacts on a person's online social network provides more opportunities for that person to search and share information on their online social network. In this study, the number of ties is represented by the number of online social networking accounts as well as the number of friends on 
Facebook (FB) and WhatsApp (WA), and WhatsApp Groups (WAG) owned by the city residents. However, number of friends on FB has the highest loading factor, meaning that the number of ties is mainly determined by this indicator. Hence, it can be inferred that the number of friends of Facebook enables a person to have more information sources, as well as greater coverage. These two things have spurred the intention to seek information from smart city digital platform and the intention to share the information on smart city websites/applications in their cities.

Furthermore, the analysis results also indicate that other online social network attribute, namely the diversity of online social network friends (diversity of ties) has positive effect on the intention to seek and share information on smart city websites/applications ( $\mathrm{H} 3 \mathrm{a}$ and $\mathrm{H} 3 \mathrm{~b}$ are supported). Diversity of ties shows the diversity of friends' backgrounds that city residents have on FB and WAG. The diversity of friends that one has on online social network provides an advantage, because they have more information options to choose from (Sanz-Cruzado \& Castells, 2018; Isaac \& Matous, 2017). The diversity of friends on online social network also makes the sources of information owned by city residents more diverse, so that they can be tailored according to needs of city residents. These increase the intentions of city residents to find and share information on smart city website/application in their city or share smart city information on their online social network.

\section{Conclusion}

This study aims to analyze the effects of perceived usefulness and online social network attributes (number of ties and diversity of ties) on the intentions to seek and to share information on smart city websites and applications. Based on the analysis results; it is concluded that the perceived usefulness, number of ties, and diversity of ties have positive and significant effects on the intention of city residents to seek and share information on smart city websites and applications. This means that the more complete the information on smart city website and application, and the more appropriate it is to the needs of city residents and to keep abreast of the latest situation, the higher the intentions of city residents to search for and share information on smart city website and application. Likewise, if there are more friends on online social networks and more diverse backgrounds of members of these online social networks, the higher the intentions of city residents to seek and share information on smart city websites and applications. 
The results of this study can be used by the city governments to manage the information provided through smart city website and application, in which the displayed information must have direct benefits for daily life of city residents. The results also implies that online social network plays an important role in information seeking and sharing. Hence, the city government can better utilize online social network to introduce or promote city development programs as well as raising the awareness regarding the smart city digital platforms.

There are some limitations to this study. First, this study is cross-sectional, where samples are taken only at one time. Research that aims to determine people's perceptions of the benefits of information should be carried out using longitudinal method so that an increase in perception from period to period can be observed. Second, the scale of some questions in the questionnaire may not accurately capture the real situation. For example, on the question of the number of friends owned on Facebook, the scale used is a multiple of 100. This wide enough interval makes someone who has few friends (eg <10 people) the same as those who have 100 friends. This interval should be narrowed so that a clear difference can be seen between groups with a large number of friends and a few. Comparative analysis with smart cities in other developing countries can also be conducted to get a more complete overview about the association between the variables studied. Future studies may address these limitations.

\section{Acknowledgment}

The authors would like to thank all of the respondents who supported this research. This work was funded by the Indonesian Ministry of Higher Education, Research and Technology/National Bureau for Research and Innovation under Grant Number NKB2678/UN2.RST/HKP.05.00/2020.

\section{Author Contribution}

Conceptualization, J. Rouli and R.D. Kusumastuti; Methodology, J. Rouli and R.D. Kusumastuti; Formal Analysis, J. Rouli and R.D. Kusumastuti; Data Curation, S.I. Syalianda dan R. Safitri; Writing - Original Draft Preparation, J. Rouli and R.D. Kusumastuti; Supervision, R.D. Kusumastuti; and Funding Acquisition, R.D. Kusumastuti. 


\section{References}

Abraham, R., Lubis, D. I., Indrawan, M., Komputer, I., Pertanian, T. I., \& Pertanian, T. (2013). Visa Masuk Kota: Alternatif Kebijakan Kaum Urban untuk Mengatasi Kepadatan Penduduk Jakarta. In Pekan Ilmiah Mahasiswa Nasional Program Kreativitas Mahasiswa - Gagasan Tertulis 2013 (Issue November 2011).

Aljowder, T., Ali, M., \& Kurnia, S. (2019). Systematic literature review of the smart city maturity model. 2019 International Conference on Innovation and Intelligence for Informatics, Computing, and Technologies, 3ICT 2019.

https://doi.org/10.1109/3ICT.2019.8910321

Angelidou, M., Psaltoglou, A., Komninos, N., Kakderi, C., Tsarchopoulos, P., \& Panori, A. (2018). Enhancing sustainable urban development through smart city applications. Journal of Science and Technology Policy Management, 9(2), 146-169. https://doi.org/10.1108/JSTPM-05-2017-0016

Anthopoulos, L., \& Fitsilis, P. (2010). From Online to Ubiquitous Cities: The Technical Transformation of Virtual Communities BT - Next Generation Society. Technological and Legal Issues (A. B. Sideridis \& C. Z. Patrikakis (Eds.); pp. 360-372). Springer Berlin Heidelberg. https://ui.adsabs.harvard.edu/abs/2010ngst.conf..360A/abstract

Anthopoulos, L. G. (2017). Understanding Smart Cities: The Rise of the Smart City. In Understanding Smart Cities: A Tool for Smart Government or an Industrial Trick? (Vol. 22). https://doi.org/10.1007/978-3-319-57015-0

Anthopoulos, L. G., \& Tougountzoglou, T. E. (2012). A Viability Model for Digital Cities: Economic and Acceptability Factors BT - Web 2.0 Technologies and Democratic Governance: Political, Policy and Management Implications (C. G. Reddick \& S. K. Aikins (Eds.); pp. 79-96). Springer New York. https://doi.org/10.1007/978-1-46141448-3_6

Anthopoulos, L., Janssen, M., \& Weerakkody, V. (2016). Smart Service Portfolios. 357-362. https://doi.org/10.1145/2872518.2888618

Badan Pusat Statistik. (2020). Catalog: 1101001. Statistik Indonesia 2020, 1101001, 790. https://www.bps.go.id/publication/2020/04/29/e9011b3155d45d70823c141f/statistikindonesia-2020.html

Berkowitz, L., \& Daniels, L. R. (1964). Affecting the salience of the social responsibility norm: effects of past help on the response to dependency relationships. The Journal of Abnormal and Social Psychology, 68(3), 275-281. https://doi.org/10.1037/h0040164

DOI: https://doi.org/10.7454/jessd.v4i1.1063 
Bock, Zmud, Kim, \& Lee. (2005). Behavioral Intention Formation in Knowledge Sharing: Examining the Roles of Extrinsic Motivators, Social-Psychological Forces, and Organizational Climate. MIS Quarterly, 29(1), 87. https://doi.org/10.2307/25148669

Boon-Itt, S. (2019). Quality of health websites and their influence on perceived usefulness, trust and intention to use: An analysis from Thailand. Journal of Innovation and Entrepreneurship, 8(1), 1-18. https://doi.org/10.1186/s13731-018-0100-9

Caragliu, A., del Bo, C., \& Nijkamp, P. (2011). Smart cities in Europe. Journal of Urban Technology, 18(2), 65-82. https://doi.org/10.1080/10630732.2011.601117

Chalik, A. A., Lay, B. W., Fauzi, A., \& Etty, R. (2011). Formulasi Kebijakan Sistem Pengolahan Sampah Perkotaan Berkelanjutan Studi Kasus: DKI Jakarta. Jurnal Permukiman, 6(1), 18-30. http://garuda.ristekbrin.go.id/documents/detail/950854

Chau, P. Y. K. (1996). An Empirical Assessment of a Modified Technology Acceptance Model. Journal of Management Information Systems, 13(2), 185-204.

https://doi.org/10.1080/07421222.1996.11518128

Chong, M., Habib, A., Evangelopoulos, N., \& Park, H. W. (2018). Dynamic capabilities of a smart city: An innovative approach to discovering urban problems and solutions. Government Information Quarterly, 35(4), 682-692. https://doi.org/10.1016/j.giq.2018.07.005

Chourabi, H., Nam, T., Walker, S., Gil-Garcia, J. R., Mellouli, S., Nahon, K., Pardo, T. A., \& Scholl, H. J. (2012). Understanding smart cities: An integrative framework. Proceedings of the Annual Hawaii International Conference on System Sciences, 2289-2297. https://doi.org/10.1109/HICSS.2012.615

Cohen, J. (2013). Statistical power analysis for the behavioral sciences. Academic press. https://doi.org/10.4324/9780203771587

Constant, D, Kiesler, S., \& Sproull, L. (1994). What is mine is ours, or is it? Information Systems Research, 5(4), 400-422.

https://pubsonline.informs.org/doi/abs/10.1287/isre.5.4.400

Constant, D., Sproull, L., \& Kiesler, S. (1996). The Kindness of Strangers: The Usefulness of Electronic Weak Ties for Technical Advice. Organization Science, 7(2), 119-135. https://doi.org/10.1287/orsc.7.2.119

Davis, F. D., Bagozzi, R. P., \& Warshaw, P. R. (1989). User Acceptance of Computer Technology: A Comparison of Two Theoretical Models. Management Science, 35(8), 982-1003. https://doi.org/10.1287/mnsc.35.8.982

DOI: https://doi.org/10.7454/jessd.v4i1.1063 
Ellison, N. B., Steinfield, C., \& Lampe, C. (2007). The benefits of facebook "friends:" Social capital and college students' use of online social network sites. Journal of ComputerMediated Communication, 12(4), 1143-1168. https://doi.org/10.1111/j.10836101.2007.00367.x

Fishbein, M., \& Ajzen, I. (1975). Belief, attitude, intention and behaviour: An introduction to theory and research (Vol. 27). https://www.scinapse.io/papers/2036389121

Gardoni, M., Spadoni, M., \& Vernadat, F. (2002). Developement and Feedbacks of a New Communication Tool to Harness Information and Knowledge and Know-How in Integrated Engineering - Case Study at Eads. In Integrated Design and Manufacturing in Mechanical Engineering (pp. 77-84). Springer, Dordrecht. http://dx.doi.org/10.1007/978-94-015-9966-5_10

Giffinger, R., Fertner, C., Kramar, H., \& Meijers, E. (2007). City-ranking of European medium-sized cities. Cent. Reg. Sci., 1-12. http://www.smartcityranking.eu/download/city_ranking_final.pdf

Granovetter, M. (1973). The strength of weak ties. American journal of sociology, 78(6), 1360-1380. https://doi.org/10.1086/225469

GSMA. (2013). Guide to Smart City: The Opportunity for Mobile Operators. GSMA. https://www.gsma.com/iot/wp-content/uploads/2013/02/cl_sc_guide_wp_02_131.pdf

Hair, J. F., Ringle, C. M., \& Sarstedt, M. (2011). PLS-SEM: Indeed a silver bullet. Journal of Marketing Theory and Practice, 19(2), 139-152. https://doi.org/10.2753/MTP10696679190202

Hair, J., Hult, G. T., Ringle, C., \& Sarstedt, M. (2017). A primer on partial least squares structural equation modeling (PLS-SEM). Sage publications. https://us.sagepub.com/enus/nam/a-primer-on-partial-least-squares-structural-equation-modeling-plssem/book 244583

Hampton, K. N. (2011). Comparing bonding and bridging ties for democratic engagement everyday use of communication technologies within social networks for civic and civil behaviors. Information Communication and Society, 14(4), 510-528.

https://doi.org/10.1080/1369118X.2011.562219

Harahap, F. R. (2013). Dampak Urbanisasi Bagi Perkembangan Kota Di Indonesia. Society, 1(1), 35-45. https://doi.org/10.33019/society.v1i1.40 
Harrison, C., Eckman, B., Hamilton, R., Hartswick, P., Kalagnanam, J., Paraszczak, J., \& Williams, P. (2010). Foundations for Smarter Cities. IBM Journal of Research and Development, 54(4), 1-16. https://doi.org/10.1147/JRD.2010.2048257

Hollands, R. G. (2008). Will the real smart city please stand up? Intelligent, progressive or entrepreneurial? City, 12(3), 303-320. https://doi.org/10.1080/13604810802479126

Hou, L., Xie, J., Zhao, J., Zhao, M., Fan, M., Xiao, Q., Liang, J., \& Chen, F. (2017). Roles of different initial Maillard intermediates and pathways in meat flavor formation for cysteine-xylose-glycine model reaction systems. In Food Chemistry (Vol. 232, pp. 135144). https://doi.org/10.1016/j.foodchem.2017.03.133

Isaac, M. E., \& Matous, P. (2017). Social network ties predict land use diversity and land use change: a case study in Ghana. Regional Environmental Change, 17(6), 1823-1833. https://doi.org/10.1007/s10113-017-1151-3

Jahmani, K., Fadiya, S. O., Abubakar, A. M., \& Elrehail, H. (2018). Knowledge content quality, perceived usefulness, KMS use for sharing and retrieval: A flock leadership application. VINE Journal of Information and Knowledge Management Systems, 48(4), 470-490. https://doi.org/10.1108/VJIKMS-08-2017-0054

JSC LAB. (2020). Jakarta Smart City. JSC LAB. https://smartcity.jakarta.go.id/new/

Kanter, R. M., \& Litow, S. S. (2009). Informed and Interconnected: A Manifesto for Smarter Cities. Harvard Business School General Management Unit Working Paper, (09-141). https://dx.doi.org/10.2139/ssrn.1420236

KOMINFO. (2017). Individu memiliki Smarphone. Survey Penggunaan TIK 2017, 18-19.

Lombardi, P., Giordano, S., Farouh, H., \& Yousef, W. (2012). Modelling the smart city performance. Innovation: The European Journal of Social Science Research, 25(2), 137-149. https://doi.org/10.1080/13511610.2012.660325

Nam, T., \& Pardo, T. A. (2011). Conceptualizing smart city with dimensions of technology, people, and institutions. ACM International Conference Proceeding Series, 282-291. https://doi.org/10.1145/2037556.2037602

Nuseir, M. T. (2020). Is advertising on social media effective? An empirical study on the growth of advertisements on the Big Four (Facebook, Twitter, Instagram, WhatsApp). International Journal of Procurement Management, 13(1), 1-9. https://doi.org/10.1504/ijpm.2020.105191 
Park, J. H., Gu, B., Leung, A. C. M., \& Konana, P. (2014). An investigation of information sharing and seeking behaviors in online investment communities. Computers in Human Behavior, 31(1), 1-12. https://doi.org/10.1016/j.chb.2013.10.002

Park, J., Konana, P., Gu, B., \& \& Leung, A. (2010). An Investigation of Information Sharing and seeking Behaviors in Virtual Communities. ICIS 2010 Proceedings, 242. https://aisel.aisnet.org/icis2010_submissions/242

Pinochet, L. H. C., Romani, G. F., de Souza, C. A., \& Rodríguez-Abitia, G. (2019). Intention to live in a smart city based on its characteristics in the perception by the young public. Revista de Gestão, 26(1), 73-92. https://doi.org/10.1108/rege-06-2018-0077

Saadé, R., \& Bahli, B. (2005). The impact of cognitive absorption on perceived usefulness and perceived ease of use in on-line learning: An extension of the technology acceptance model. Information and Management, 42(2), 317-327. https://doi.org/10.1016/j.im.2003.12.013

Sairamesh, J., Lee, A., \& Anania, L. (2004). Session details: Information cities. Communications of the ACM, 47(2), 3263538. https://doi.org/10.1145/3263538

Sanz-Cruzado, J., \& Castells, P. (2018). Enhancing structural diversity in social networks by recommending weak ties. RecSys 2018 - 12th ACM Conference on Recommender Systems, 233-241. https://doi.org/10.1145/3240323.3240371

Savolainen, R. (2019). Modeling the interplay of information seeking and information sharing: A conceptual analysis. Aslib Journal of Information Management, 71(4), 518534. https://doi.org/10.1108/AJIM-10-2018-0266

Shapiro, J. M. (2006). Growth Effects of Human Capital. The Review of Economics and Statistics, 88(May), 324-335. https://www.nber.org/papers/w11615

Skvoretz, J. (2013). Diversity, integration, and social ties: Attraction versus repulsion as drivers of intra- and intergroup relations. American Journal of Sociology, 119(2), 486517. https://doi.org/10.1086/674050

Sproull, L., \& Patterson, J. F. (2004). Making information cities livable. Communications of the ACM, 47(2), 33-37. https://doi.org/10.1145/966389.966412

Sukarto, H. (2006). PEMILIHAN MODEL TRANSPORTASI di DKI JAKARTA dengan ANALISIS KEBIJAKAN “PROSES HIRARKI ANALITIK .” 3(1), 25-36. https://sipiluph.tripod.com/vol3.1.3.pdf 
Sussman, S. W., \& Siegal, W. S. (2003). Informational influence in organizations: An integrated approach to knowledge adoption. Information Systems Research, 14(1), 4765. https://doi.org/10.1287/isre.14.1.47.14767

Titmuss, R. M. (2018). The gift relationship (reissue): From human blood to social policy. Bristol: Bristol University Press. https://doi.org/10.2307/j.ctv6zdcmh

Toppeta, D. (2010). The Smart City Vision: How Innovation and ICT Can Build Smart, in Livable, "Sustainable Cities. http://www.thinkinnovation.org/file/research/23/en/Toppeta_Report_005_2010.pdf.

Van Soom, E. (2009). Measuring levels of supply and demand for e-services and egovernment: a toolkit for cities. Smart cities research brief, 3 .

https://lirias.kuleuven.be/retrieve/215279

Venkatesh; Viaswanath, \& Davis; Fred D. (2000). A Theoretical Extension of the Technology Acceptance Model: Four Longitudinal Field Studies. Management Science, 46(2), 186-204.

Wang, Yanyan; Zhao, Y. (2017). Seeking information through weak ties on Facebook. IConference 2017 Proceedings. https://doi.org/10.9776/17366

Washburn, D., \& Sindhu, U. (2009). Helping CIOs understand "smart city" initiatives. Growth, 17(2), 1-17.

https://www.itworldcanada.com/archive/Themes/Hubs/Brainstorm/forrester_help_cios_s mart_city.pdf

Wasko, M. M. L., \& Faraj, S. (2005). Why should I share? Examining social capital and knowledge contribution in electronic networks of practice. MIS Quarterly: Management Information Systems, 29(1), 35-57. https://doi.org/10.2307/25148667

Weng, L., Karsai, M., Perra, N., Menczer, F., \& Flammini, A. (2018). Attention on Weak Ties in Social and Communication Networks. In Complex spreading phenomena in social systems (pp. 213-228). Springer, Cham. https://doi.org/10.1007/978-3-319-773322_12

Widmayer, P. (1999). Building Digital Metropolis: Chicago's Future Networks. IT Professional, 1(4), 40-46. https://doi.org/10.1109/6294.781624

Wilson, T. D. (2000). Human information behavior. Informing Science, 3(2), 49-55. https://doi.org/10.28945/576 
Yudo, S., \& Said, N. I. (2001). Masalah Pencemaran Air Di Jakarta, Sumber Dan Alternatif Penanggulangannya. Jurnal Teknologi Lingkungan, 2(2), 199-206.

https://ejurnal.bppt.go.id/index.php/JTL/article/view/214

Zorzi, O. (2019). Granovetter (1983): The strength of weak ties: A network theory revisited. In Schlüsselwerke der Netzwerkforschung (pp. 243-246). Springer VS, Wiesbaden. https://doi.org/10.1007/978-3-658-21742-6_55 